\title{
Three new species of the ectoparasitic mites of the genus Syringophiloidus Kethley, 1970 (Acari: Syringophilidae) from passeriform birds from Slovakia
}

\author{
Maciej Skoracki \\ Department of Animal Morphology, A. Mickiewicz University, 28 Czerwca 1956 r. nr 198, 61-485 Poznań, Poland
}

Key words: Syringophilidae, Syringophiloidus, taxonomy, ectoparasites, Passeriformes

\begin{abstract}
Three new quill mite species of the genus Syringophiloidus Kethley, 1970 (Acari: Syringophilidae) from Slovakia are described and figured: S. bombycillae sp. n. from the waxwing Bombycilla garrulus (L.) (Passeriformes: Bombycillidae), $S$. schoeniclus sp. n. from the reed bunting Emberiza schoeniclus L. (Passeriformes: Emberizidae) and S. montanus sp. n. from the tree sparrow Passer montanus (L.) (Passeriformes: Ploceidae). A key to all known species of the genus Syringophiloidus is given.
\end{abstract}

The fauna of the ectoparasitic mites of the genus Syringophiloidus Kethley, 1970 includes 11 described species. Most of them are associated with passeriform birds of the families Corvidae, Fringillidae, Hirundinidae, Ploceidae, Turdidae, Sturnidae, Motacillidae, Parulidae and Laniidae (Table 1) (Fritsch 1958, Clark 1964, Chirov and Kravtsova 1995, Bochkov and Mironov 1998, Bochkov 2001, Bochkov and Apanaskevich 2001, Skoracki et al. 2001). One species was described from the Apodiformes (Apodidae) (Fain et al. 2000). Species of this genus are small to mediumsized mites and they live in various parts of plumage: inside the quills of the primaries, secondaries, alulars, rectrices, greater coverts and tail coverts (Kethley 1970, Casto 1974).

In the present paper are given descriptions of three new species of the genus Syringophiloidus associated with passeriform birds from Slovakia: the waxwing Bombycilla garrulus (L.) (Bombycillidae), the reed bunting Emberiza schoeniclus L. (Emberizidae) and the tree sparrow Passer montanus (L.) (Ploceidae). The Bombycillidae and Emberizidae are new host families for the genus Syringophiloidus. All these new species were found inside the quills of secondary feathers.

\section{MATERIALS AND METHODS}

Syringophilid mite specimens were acquired from the bird collection deposited in the Department of Natural History, the Šarišské Múzeum, Bardejov, Slovakia. Flight feathers $\left(5^{\text {th }}\right.$ right secondary), undertail and body (from the ventral area) feathers were removed and examined. Mites were mounted in a polyvinylolactophenol medium in microscopic slides and studied with a differential interference (Nomarski) contrast Olympus BH 2 microscope.

The nomenclature of idiosomal setae follows that of Fain (1979) in the version adapted for the family Syringophilidae (Bochkov and Mironov 1998). The terminology and leg chaetotaxy follows these of Kethley (1970) and Grandjean
(1944). Bird taxonomy follows that of Morony et al. (1975). All measurements are given in micrometres $(\mu \mathrm{m})$. The setal measurements of holotypes are incomplete, because some setae were broken.

Abbreviations for the institutions where the type materials are deposited: UAM - Department of Animal Morphology, A. Mickiewicz University, Poznań, Poland, SMB - Department of Natural History, the Šarišské Múzeum, Bardejov, Slovakia, ZIN - Zoological Institute of the Russian Academy of Sciences, St. Petersburg, Russia.

\section{RESULTS}

Syringophiloidus bombycillae sp. $\mathrm{n}$.

Figs. 1-8

Female (Figs. 1, 2, 5, 6). Total body length of holotype 725 (750-925 of 7 paratypes).

GNATHOSOMA. Gnathosoma punctated ventrally. Hypostomal apex as in Fig. 5. Peritremes M-shaped, each transversal branch with 5-7 chambers, each longitudinal branch with 10-12 chambers (Fig. 6). Stylophore 180 (180-195) long.

IDIOSOMA. Propodosomal plate well sclerotised, the bases of setae vi, ve, sci, $d 1$ and sce on this plate. Setae $v i$, ve and $s c i$ weakly serrate. Length ratio of setae $v i$ : ve : sci 1 : 1.6-1.8 : 4.7. Hysterosomal plate fused to pygidial plate, weakly sclerotised, margins indistinct; bases of setae $l 1, d 2$ and $l 2$ on or near this plate, setae $l 4$ and $d 4$ on this plate. Setae $d 2$ closer to $l 1$ than to $l 2$. The ratio of distances between setal bases $l 1-d 2: d 2-l 21: 2$. Length ratios of setae $d 5: l 5$ and $d 4: l 41: 14-15$ and 1 : 7-8.8, respectively. Paragenital setae pg1 1.2-1.4 times longer than $p g 2$. Two pairs of anal setae. Dorsal plates not punctated. Cuticular striations as in Figs. 1 and 2.

LEGS. All coxae punctated. Epimeres I parallel and adjoining to epimeres II. Setae $p$ ' and $p$ " of legs III and IV with 6-7 tines. Setae $t c^{\prime}$ of tarsi III and IV twice shorter than $t c$ " III and IV. Setae $3 c$ three times longer than $3 b$. 


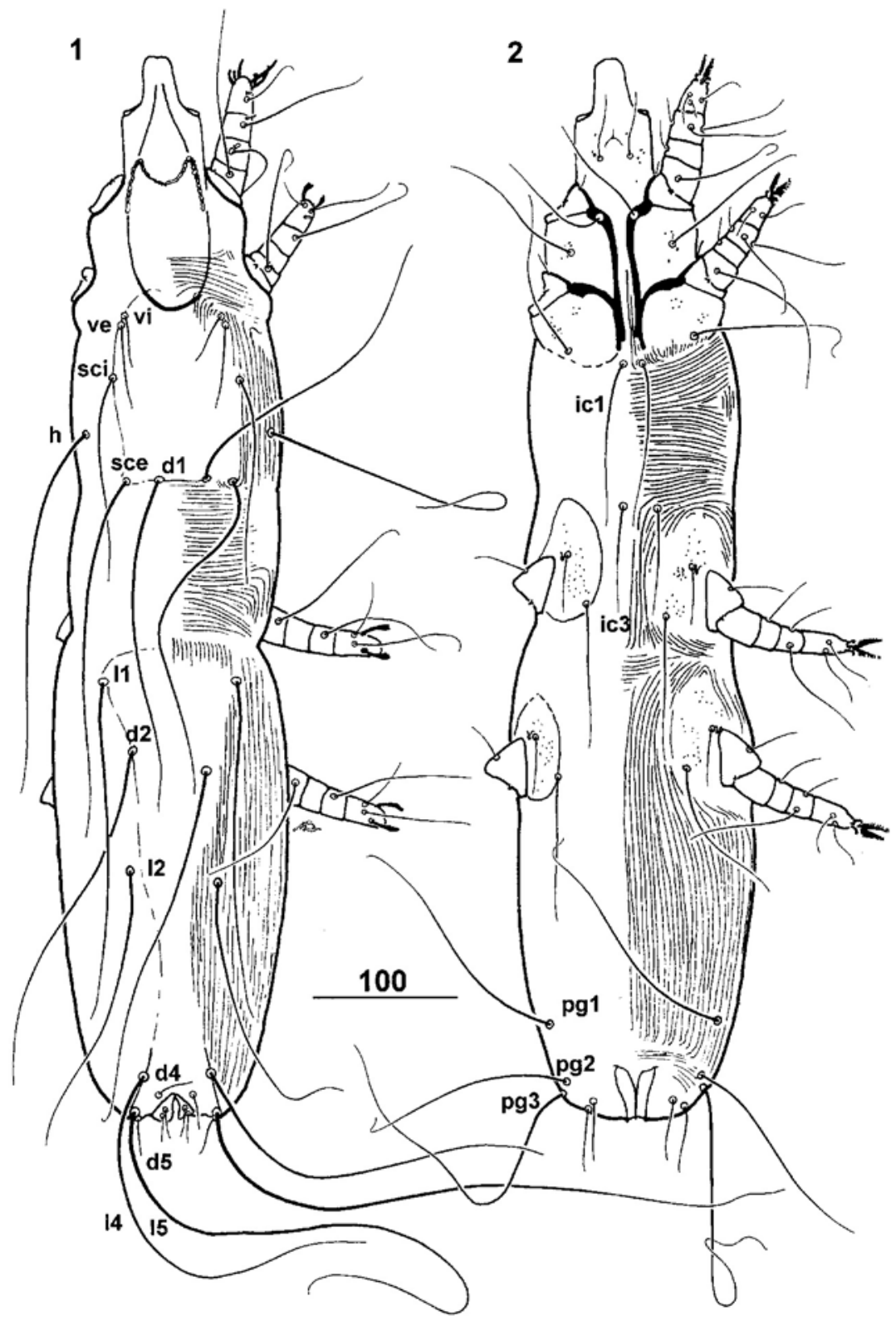

Figs. 1, 2. Syringophiloidus bombycillae sp. n., female. Fig. 1. Dorsal view. Fig. 2. Ventral view. Scale bar in $\mu \mathrm{m}$.

Length of setae and distance between setal bases ( $\mathrm{n}=$ 7): vi 35 (30-45); ve 60 (55-70); sci 165 (130); $h 250$ (195-240); sce 250 (225-250); l1 250 (225-260); l2 (190-215); $l 5$ (405-450); $d 530$ (30); d1 (225-245); $d 2$ 250 (250); 14295 (255-265); d4 (30-35); al 25 (20-25); a2 25 (20-25); g1 (35-40); g2 (35-40); icl (100-150); ic3 (70); scl (10); sc2 (15); sc3 50 (40-50); sc4 (30-40); pg1 190 (165-200); pg2 (135-165); pg3 245 (240-250); $3 b$ 30-35; $3 c$ 100-105; tc' of tarsi III and IV (40-50); $t c$ " of tarsi III and IV (90-100); vi-vi 85 (80-85); ve-ve 90 (90); sci-sci 105 (100-105); h-h 120 (120-130); dl-dl 35 (30-35); sce-sce 85 (70-85); vi-ve 10 (7-10); ve-sci 25 (25-35); sci-sce 85 (70-80); l1-ll 95 (95-100); d2-d2 60 (60-65); l2-l2 (115); ll-d2 50 (50-60); d2-l2 95 (100$115)$.
Male (Figs. 3, 4, 7, 8). Total body length of one paratype 450.

Gnathosoma. Hypostomal apex as in Fig. 7. Peritremes M-shaped, each transversal branch with 6 chambers, each longitudinal branch with 9-13 chambers (Fig. 8). Stylophore 165 long.

IDIOSOMA. Propodosomal plate weakly sclerotised, margins indistinct, not punctated. Bases of setae vi, ve, $s c i$, and $d l$ on this plate; bases of setae sce near this plate. Length ratio of setae $v i$ : ve : sci $1: 1.5: 2$. Hysterosomal plate poorly developed or absent. Small pygidial plate present, setae $d 5$ and $l 5$ on this plate. Setae $d 2$ closer to $l 1$ than to $l 2$ or equidistant to $l 1$ and l2. Length ratio of setae $d 5: l 51: 11-13$. Two pairs of anal setae. Paragenital setae pgl 1.6-1.8 times longer than $p g 2$. Cuticular striations as in Figs. 3 and 4. 


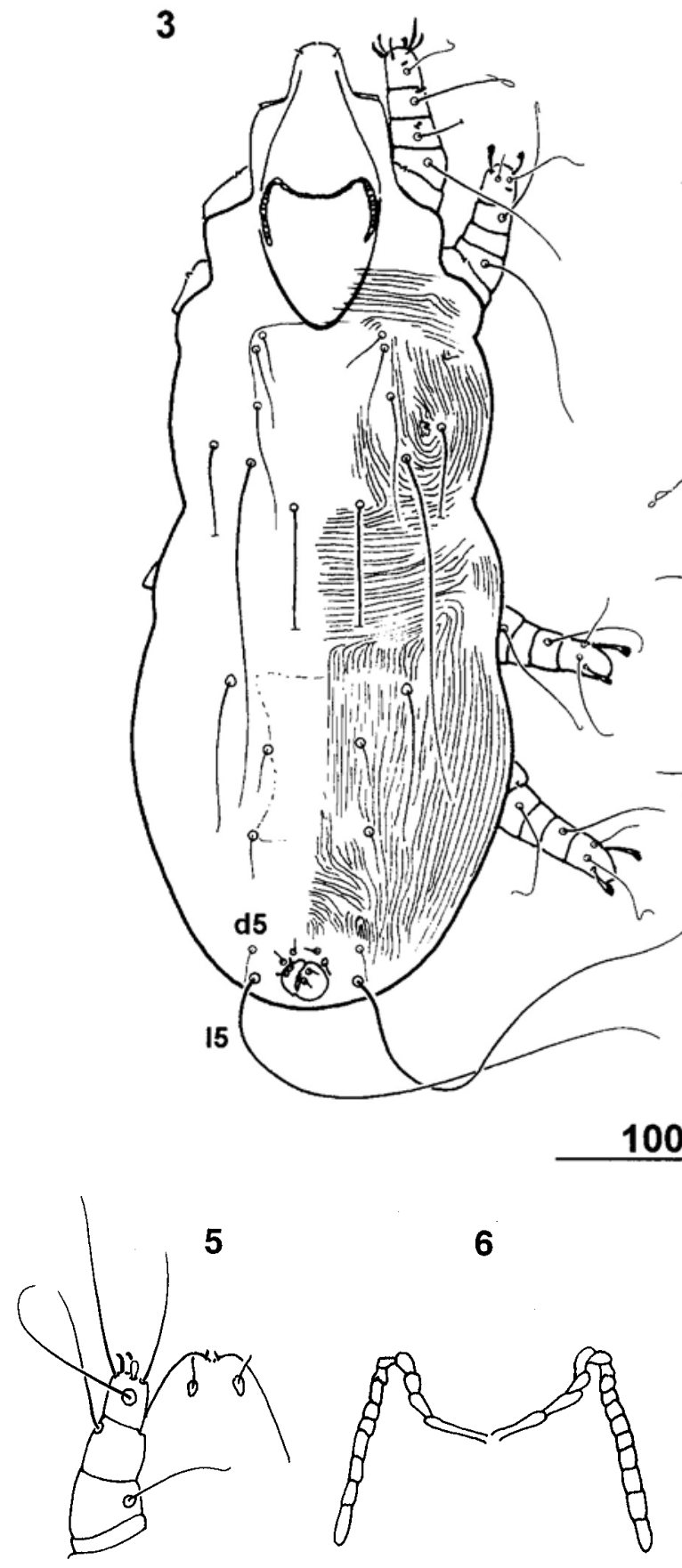

4

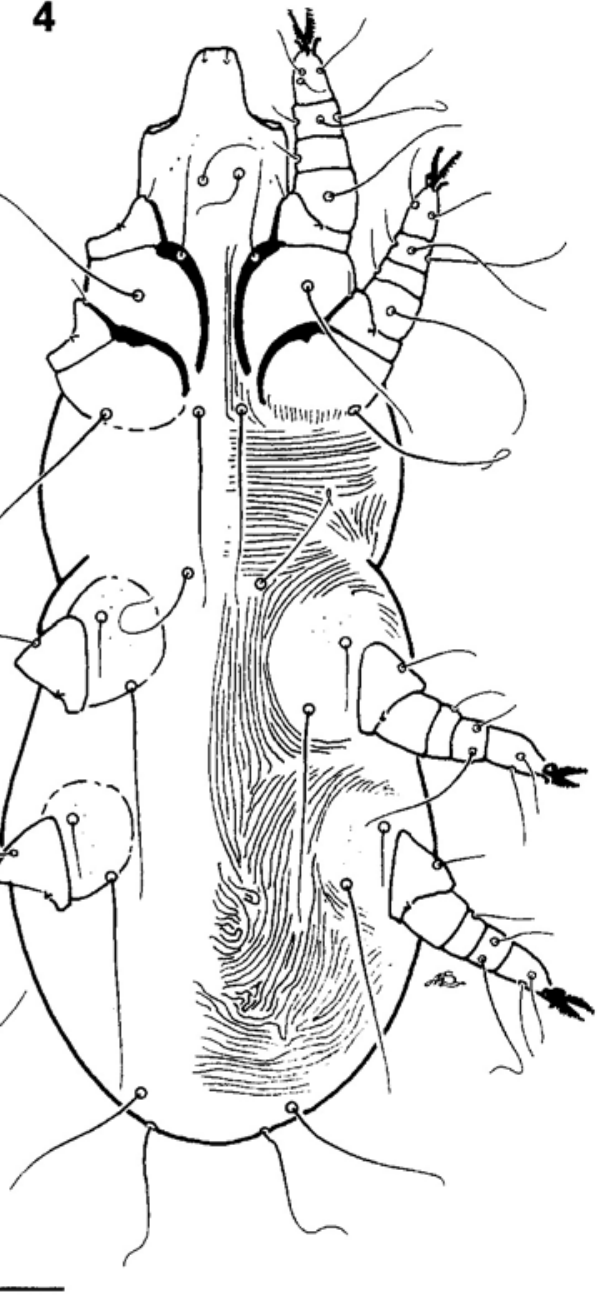

7

8

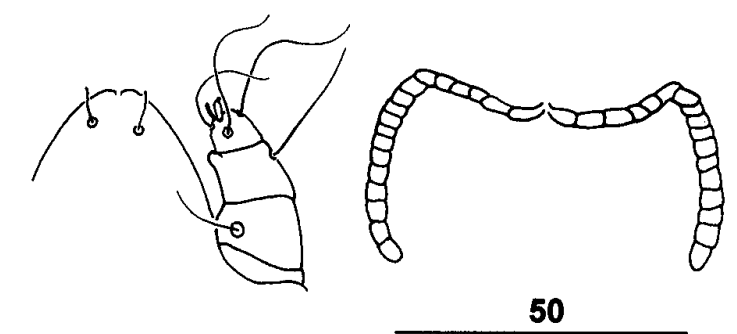

Figs. 3-8. Syringophiloidus bombycillae sp. n. Fig. 3. Male, dorsal view. Fig. 4. Male, ventral view. Fig. 5. Hypostomal apex, female. Fig. 6. Peritremes, female. Fig. 7. Hypostomal apex, male. Fig. 8. Peritremes, male. Scale bars in $\mu \mathrm{m}$.

LEGS. All coxae well sclerotised, not numerously punctated or without punctation. Epimeres I divergent, not fused to epimeres II. Setae $p$ ' and $p$ " of legs III and IV with 6-8 tines. Setae $t c$ ' of tarsi III and IV 2.3-2.6 times shorter than $t c$ " III and IV.

Length of setae and distance between setal bases $(\mathrm{n}=$ 2): vi 25-30; ve 45; $h$ 60; sce 190; l1 70;l2 15-20;l5 260-275; d5 20-25; sc1 10; sc2 15; sc3 30-35; sc4 25; pg1 110-140; pg2 60-90; tc' of tarsi III and IV 30; tc" of tarsi III and IV 70-80; vi-vi 75; ve-ve 85; sci-sci 85-90; $h-h$ 120-130; dl-dl 35-45; sce-sce 90-105; vi-ve 7; vesci 20-25; sci-sce 35-45; sci-d1 60-65; l1-l1 90-100; d2d2 50; l2-l2 50; l1-d2 35; d2-l2 45 .

$\mathrm{T}$ y p e h o s t : Bombycilla garrulus (L.) (Passeriformes: Bombycillidae), the waxwing.

S i t e : Quills of secondary feathers. 

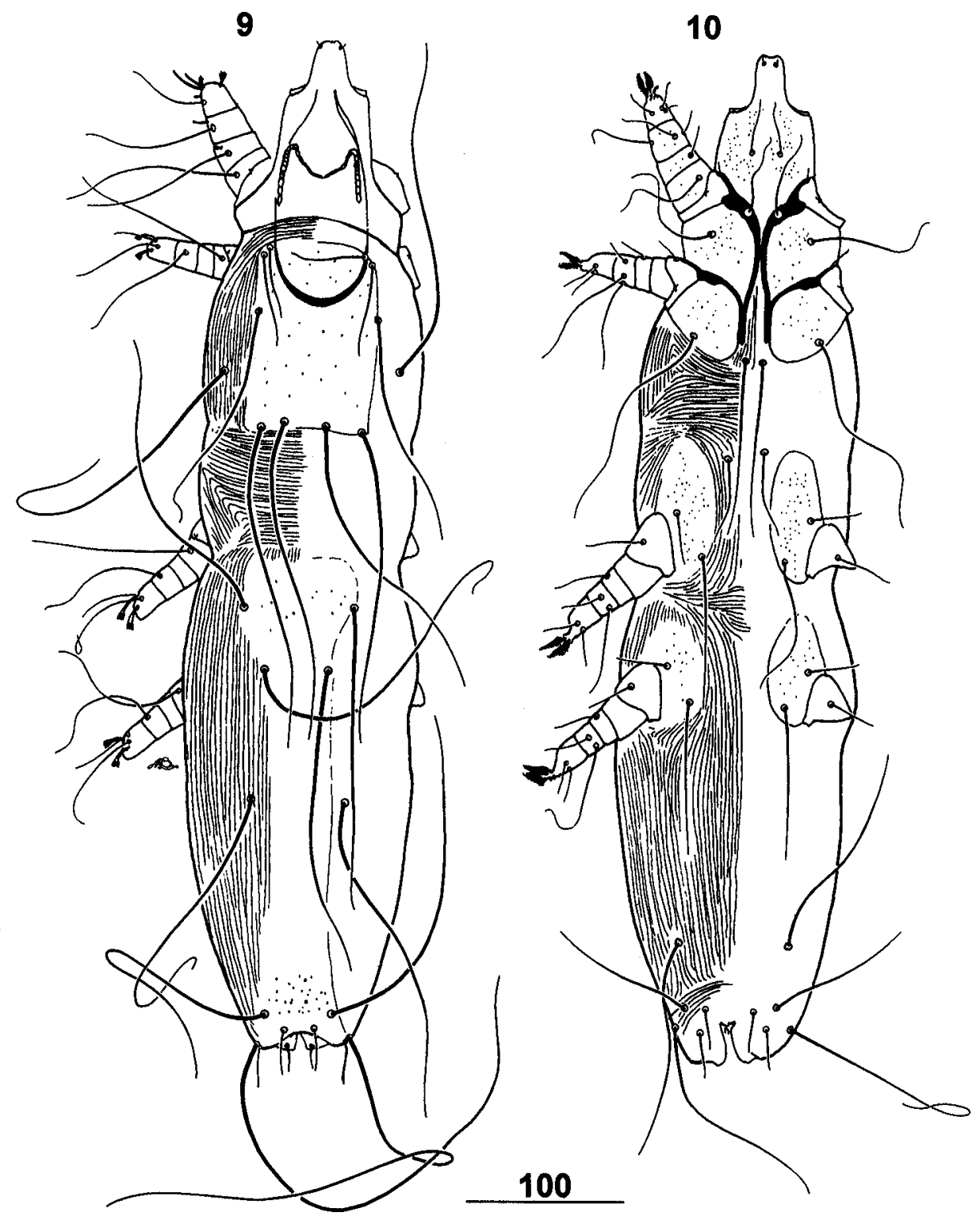

Figs. 9, 10. Syringophiloidus schoeniclus sp. n., female. Fig. 9. Dorsal view. Fig. 10. Ventral view. Scale bar in $\mu \mathrm{m}$.

T y p e 1 o c a 1 i t y : Bardejov, Slovakia; 14.12.1962; leg. T. Weisz.

T y p e s p e c i m e n s: Holotype female and 8 paratype females, 3 paratype males and 2 paratype nymphs.

D e p o s ition of m at e r i a 1 : Holotype (No. S-14.1.1), 4 female, 2 male and 2 nymphal paratypes (Nos. S-14.1.2 S-14.1.9) are deposited at UAM; 2 female paratypes (Nos. S-14.1.10, S-14.1.11) are deposited at SMB; 2 female and 1 male paratypes (Nos. S-14.1.12 - S-14.1.14) are deposited at ZIN.

E t y m o log y: The name bombycillae refers to the generic name of the host - Bombycilla garrulus.

Differential diagnosis. Syringophiloidus bombycillae is closest to $S$. graculae Fain, Bochkov et Mironov, 2000 from Gracula religiosa intermedia (Passeriformes:
Sturnidae). In both species, the females have the setae $v i$ and ve shorter than 90 and sci longer than 90; the males, have setae $l 1$ much longer than setae $d 2$ and $l 2$.

This new species is distinguished from $S$. graculae by the following characters: In females of $S$. bombycillae, the total body length is 725-925, the transversal branches of peritremes have 5-7 chambers and the length of setae $s c i$ and $l 5$ is 130-165 and 405450 , respectively; in males the length of setae $h$ and $l 5$ is 60 and 260-270, respectively. In females of $S$. graculae the total body length is 615-680, the transversal branches of peritremes have 3 chambers and the length of setae $s c i$ and $l 5$ is $190-245$ and 290-305, respectively; in the males, length of setae $h$ and $l 5$ is $130-140$ and 145-150, respectively. 
11

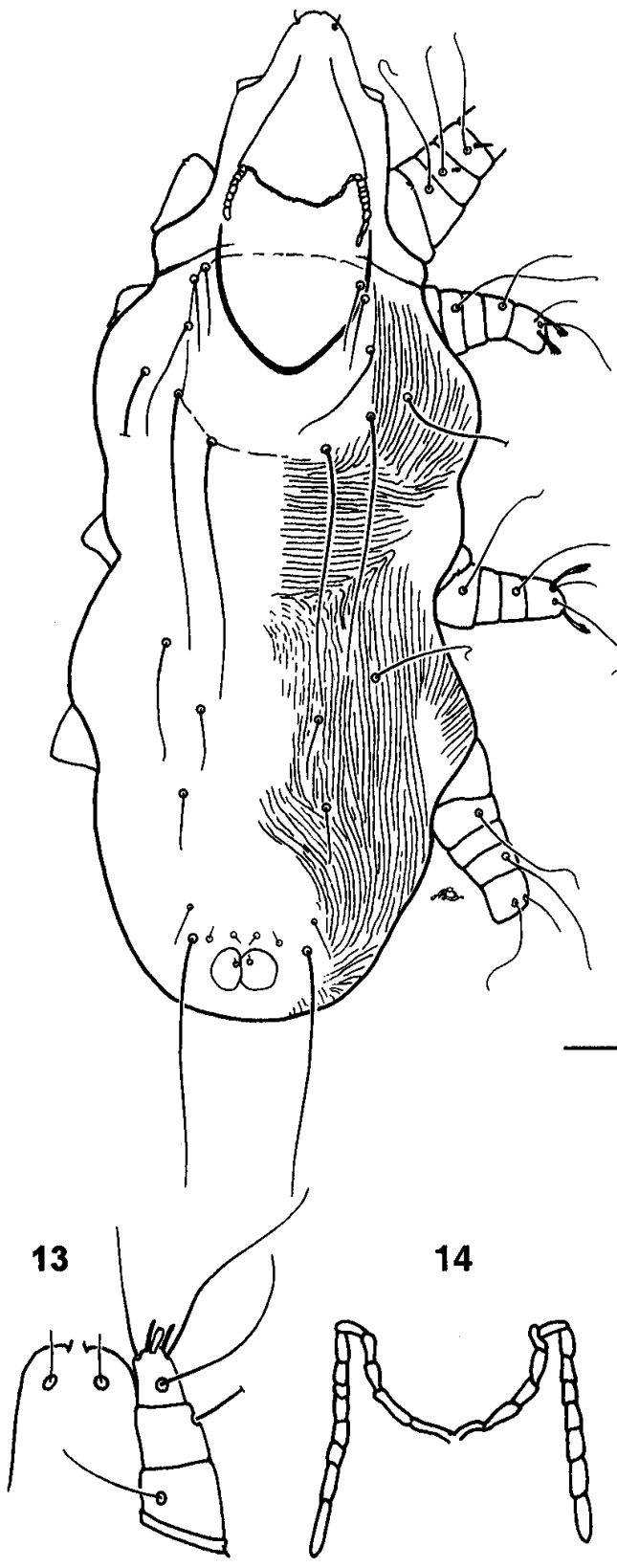

12

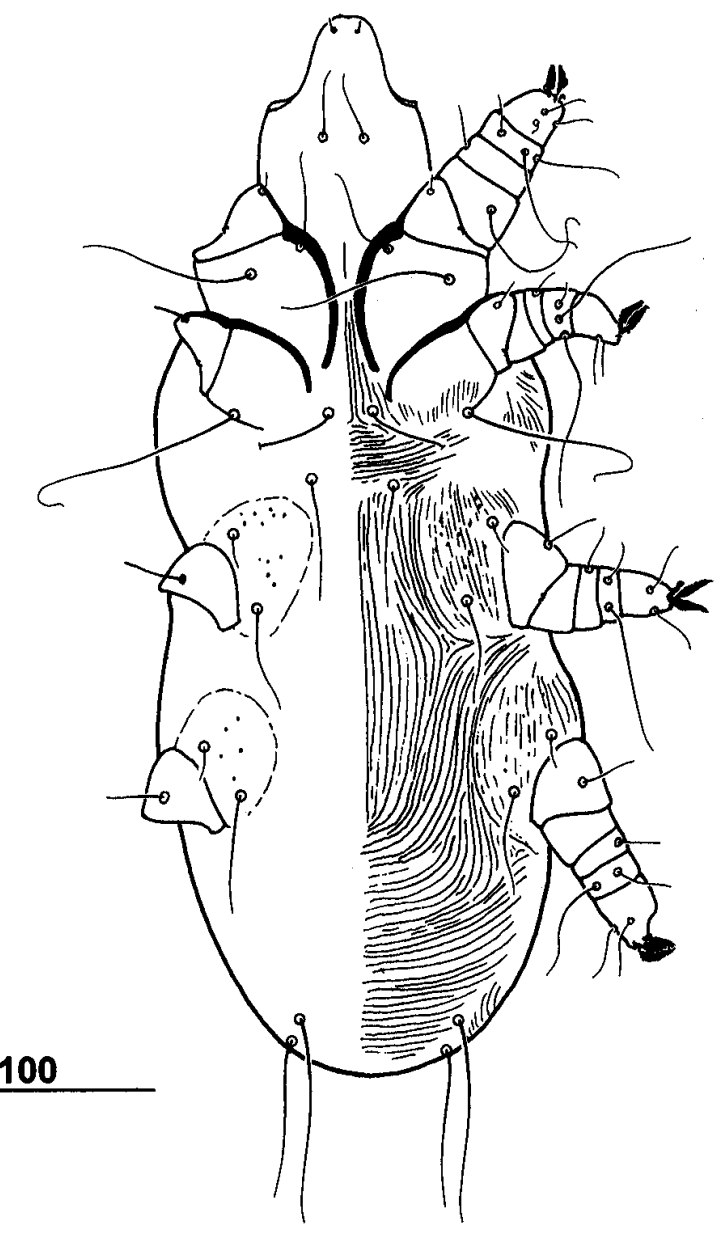

15

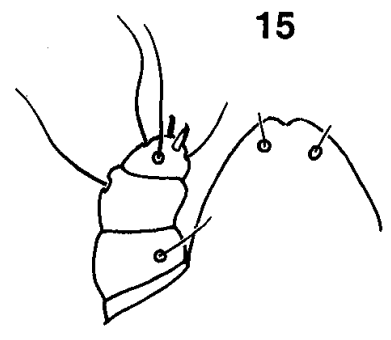

16

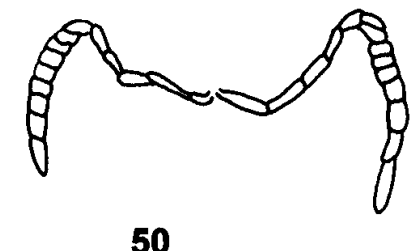

Figs. 11-16. Syringophiloidus schoeniclus sp. n. Fig. 11. Male, dorsal view. Fig. 12. Male, ventral view. Fig. 13. Hypostomal apex, female. Fig. 14. Peritremes, female. Fig. 15. Hypostomal apex, male. Fig. 16. Peritremes, male. Scale bars in $\mu \mathrm{m}$.

\section{Syringophiloidus schoeniclus sp. n. \\ Figs. 9-16}

Female (Figs 9, 10, 13, 14). Total body length of holotype 675 (650-750 of 10 paratypes).

GNATHOSOMA. Gnathosoma punctated ventrally. Hypostomal apex as in Fig. 13. Peritremes M-shaped, each transversal branch with 4-5 chambers, each longitudinal branch with 7-9 chambers (Fig. 14). Stylophore 175 (170-180) long.
IDIOSOMA. Propodosomal plate well sclerotised and punctated. The bases of setae $v i, v e, s c i, s c e$ and $d l$ on this plate. Setae vi, ve and $s c i$ serrate. Length ratio of setae $v i:$ ve : sci $1: 1.1: 2.3$. Hysterosomal plate fused to pygidial plate, anterior and posterior parts with punctation. The bases of setae $l 1$ and $d 2$ on this plate. Setae $d 2$ closer to $l 1$ than to $l 2$. The ratio of distances between setal bases $l 1-d 2: d 2-l 2$ about $1: 2$. Length ratios of setae $d 5: l 5$ and $d 4: l 41: 12.5-13.2$ and $1: 8-8.8$, 
respectively. Paragenital setae $p g 1$ 1.6-1.8 times longer than pg2. Only one pair of anal setae present. Cuticular striations as in Figs. 9 and 10.

LEGS. All coxae well sclerotised and punctated. Epimeres I parallel and adjoining the epimeres II. Setae $p$ ' and $p$ " of legs III and IV with 6 tines. Setae $t c^{\prime}$ of tarsi III and IV 1.4-1.6 times shorter than $t c$ " III and IV. Setae $3 c$ 3.1-3.4 times longer than $3 b$.

Length of setae and distance between setal bases $(\mathrm{n}=$ 10): vi 55 (40-55); ve 60 (50-65); sci 130 (130-165); $h$ (215-250); sce (215-230); ll (190-220); l2 (170-230); l5 355 (330-375); d5 (25-30); d1 215 (200-225); d2 205 (200-205); 14240 (220-240); d4 (25-30); al 20 (20-25); a2 absent; g1 25 (20-30); g2 25 (20-30); icl (110-130); ic3 (70); pgl (150-165); pg2 85 (105); pg3 175 (150170); $3 b$ (25-35); 3c (85-110); scl (10); sc2 (15); sc3 40 (40-50); sc4 (25-35); tc' of tarsi III and IV 50 (40-50); tc" of tarsi III and IV 70 (70-80); vi-vi 60; ve-ve 70; scisci 80 (80-95); h-h 115 (120); dl-dl 25 (30); sce-sce 65 (70); vi-ve 7 (7-10); ve-sci 40 (35-40); sci-sce 75 (75); $l 1-l 170$ (70); d2-d2 40 (40); l2-l2 60 (60); l1-d2 40 (50); d2-l2 90 (85).

Male (Figs. 11, 12, 15, 16). Total body length of two paratypes 400 and 430 .

GNATHOSOMA. Gnathosoma not punctated ventrally. Hypostomal apex as in Fig. 15. Peritremes M-shaped, each transversal branch with 5-6 chambers, each longitudinal branch with 8 chambers (Fig. 16). Stylophore 150-165 long.

IDIOSOMA. Propodosomal plate well sclerotised, without punctation. The bases of setae vi, ve, sci, and $d l$ on this plate. Length ratio of setae $v i$ : ve : sci $1: 1.3-1.5$ : 2-2.5. Setae $l 2$ about twice longer than $d 2$ and $l 2$. Pygidial plate present. Length ratio of setae $d 5: l 51$ : 5.5-6.3. One pair of anal setae. Paragenital setae $p g 1$ and pg2 subequal in length. Cuticular striations as in Figs. 11 and 12.

LEGS. Coxae of legs III and IV weakly sclerotised. Epimeres I slightly divergent and not fused to epimeres II. Setae $p$ ' and $p$ " of legs III and IV with 6 tines. Setae $t c$ ' of tarsi III and IV 2.3 times shorter than $t c$ " III and IV.

Length of setae and distance between setal bases $(\mathrm{n}=$ 2): vi 15-20; ve 25-30; sci 40; sce 115; l1 40-45; l2 15 20; 15 95-110; d1 105-110; d2 20; d5 15-20; pg1 70-80; ic3 40; pg2 60-70; $3 b$ 10-15; 3c 45; sc3 20-25; sc4 1525 ; $t c$ ' of tarsi III and IV 20 ; $t c$ " of tarsi III and IV 45 ; vi-vi 65; ve-ve 70-75; sci-sci 70; h-h 100-115; d1-d1 45; sce-sce 80-85; vi-ve 3-5; ve-sci 20-30; sci-d1 40-45; scisce 25-30; l1-l1 80-85; d2-d2 50-55; l2-l2 60; l1-d2 2530; d2-l2 30-35.

$\mathrm{T}$ y $\mathrm{p}$ e h o s t : Emberiza schoeniclus L. (Passeriformes: Emberizidae), the reed bunting. S i t e : Quills of secondary feathers.

T y p e 1 o c a 1 i t y : Slovenská Kajňa, Slovakia; 10.03.1975, leg. T. Weisz.
T y p e s p e c i m e n s : Holotype female, 16 paratype females, 2 paratype males, 3 paratype nymphs and 1 paratype larva.

D e p o s it i o n of mat e ria 1 : Holotype (No. S-15.1.1), 12 female, 1 male, 2 nymphal and 1 larval paratypes (Nos. S-15.1.2 - S-15.1.17) are deposited at UAM; 2 female paratypes (Nos. S-15.1.18, S-15.1.19) are deposited at SMB; 2 female and 1 male paratypes (Nos. S-15.1.20 - S15.1.22) are deposited at ZIN.

E t y m o log y: The name schoeniclus refers to the specific name of the host-Emberiza schoeniclus.

Differential diagnosis. This new species is distinguished from all species of the genus Syringophiloidus by the presence of one pair of anal setae in both sexes. Within the genus, S. schoeniclus belongs to the species with short setae $v i$ and ve (shorter than 90) and long setae sci (longer than 90): S. motacillae Bochkov et Mironov, 1998, S. seiurus (Clark, 1964), S. graculae Fain, Bochkov et Mironov, 2000, S. presentalis Chirov et Kravtsova, 1995 and $S$. bombycillae (this paper).

\section{Syringophiloidus montanus sp. n.}

Figs. 17-23

Female (Figs 17, 18, 20, 21). Total body length of holotype 675 (675-785 of 10 paratypes).

GNATHOSOMA. Gnathosoma punctated ventrally. Hypostomal apex as in Fig. 20. Peritremes M-shaped, each transversal branch with 6-7 chambers, each longitudinal branch with 9-10 chambers (Fig. 21). Stylophore 175 (175-180) long.

IDIOSOMA. Propodosomal plate well sclerotised, posterior margin indistinct, without punctation. The bases of setae $v i$, ve, sci, sce and $d l$ on this plate. Setae $v i$, ve and $s c i$ serrate. Length ratio of setae $v i$ : ve : sci 1 : $1.6: 3-3.4$. Hysterosomal plate present, fused to pygidial plate, punctated in posterior part, median part of this plate weakly sclerotised. The bases of setae $d 2$ on this plate. Setae $d 2$ closer to $l 1$ than to $l 2$. The ratio of distances between setal bases $l 1-d 2: d 2-l 2$ about $1: 1.6$. Length ratios of setae $d 5: l 5$ and $d 4: l 41: 14$ and $1: 10$, respectively. Paragenital setae $p g 1$ and $p g 2$ subequal in length. Two pairs of anal setae present. Cuticular striations as in Figs. 17 and 18.

LEGS. All coxae well sclerotised. Coxae of legs I and II not numerously punctated or without punctation. Coxae of legs III and IV punctated. Setae $p$ ' and $p$ " of legs III and IV with 5-6 tines. Setae $t c$ ' of tarsi III and IV twice shorter than $t c$ " III and IV. Setae $3 c$ 2.5-2.8 times longer than $3 b$.

Length of setae and distance between setal bases $(\mathrm{n}=$ 10): vi 35 (30-40); ve 50 (50-60); sci 105 (90-135); $h$ 180 (140-160); sce 190 (160-180); ll 170; l2 170 (150160); $l 5355$ (340-420); d5 25 (20-25); d1 205 (180190); $d 2$ 170; 14 (200-210); $d 425$ (20-25); al and $a 2$ (15-20); $g 1$ and g2 30 (30); icl (90-110); ic3 80 (80110); pg1 150 (155-180); pg2 140 (140-165); pg3 (180190); $3 b 35$ (30-40); 3c (85-100); scl (10); sc2 (15); sc3 $40(30-40)$; sc4 35 (30); tc' of tarsi III and IV 35 

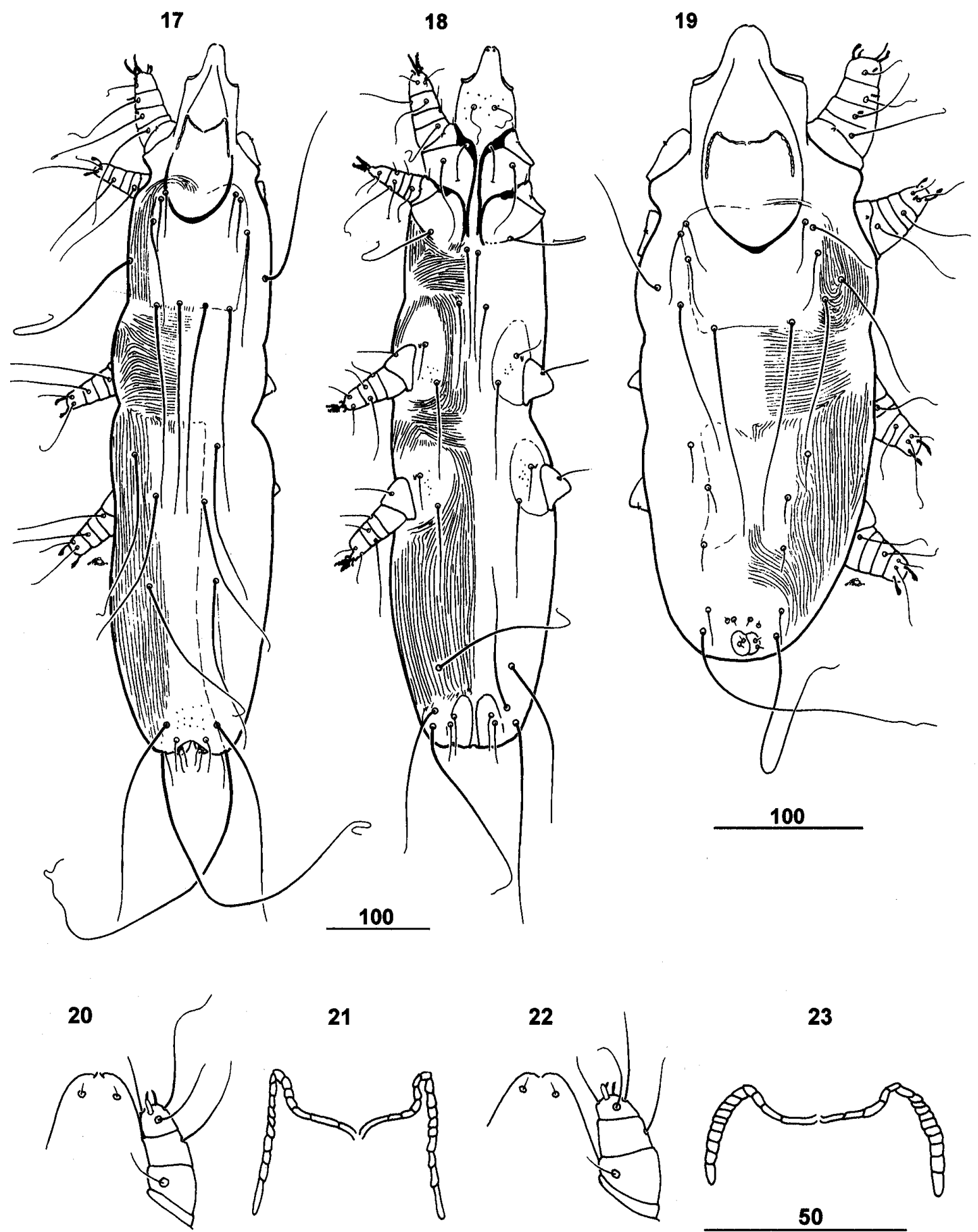

23

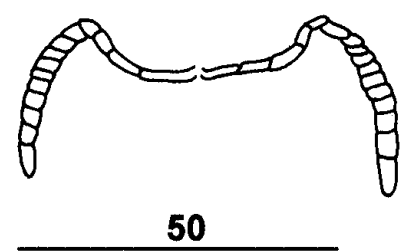

Figs. 17-23. Syringophiloidus montanus sp. n. Fig. 17. Female, dorsal view. Fig. 18. Female, ventral view. Fig. 19. Male, dorsal view. Fig. 20. Hypostomal apex, female. Fig. 21. Peritremes, female. Fig. 22. Hypostomal apex, male. Fig. 23. Peritremes, male. Scale bars in $\mu \mathrm{m}$. 
Table 1. Quill mites of the genus Syringophiloidus and their hosts.

\begin{tabular}{|c|c|}
\hline Species & Host \\
\hline $\begin{array}{l}\text { S. glandarii } \\
\text { (Fritsch, 1958) }\end{array}$ & $\begin{array}{l}\text { Garrulus glandarius* } \\
\text { (Corvidae) } \\
\text { Coccothraustes } \\
\text { coccothraustes } \\
\text { (Fringillidae) }\end{array}$ \\
\hline $\begin{array}{l}\text { S. delichonum } \\
\text { Bochkov, } 2001\end{array}$ & $\begin{array}{r}\text { Delichon urbica* } \\
\text { (Hirundinidae) }\end{array}$ \\
\hline S. bombycillae sp. $\mathrm{n}$. & $\begin{array}{l}\text { Bombycilla garrulus* } \\
\text { (Bombycillidae) }\end{array}$ \\
\hline S. montanus sp. n. & $\begin{array}{l}\begin{array}{l}\text { Passer montanus* } \\
\text { (Ploceidae) }\end{array} \\
\end{array}$ \\
\hline S. schoeniclus sp. $\mathrm{n}$. & $\begin{array}{l}\text { Emberiza schoeniclus* } \\
\text { (Emberizidae) }\end{array}$ \\
\hline $\begin{array}{l}\text { S. minor } \\
\quad \text { (Berlese, 1887) }\end{array}$ & $\begin{array}{l}\text { Passer domesticus* } \\
\text { Passer montanus } \\
\text { (Ploceidae) } \\
\text { Turdus iliacus } \\
\text { (Turdidae) } \\
\text { Sturnus vulgaris } \\
\text { (Sturnidae) }\end{array}$ \\
\hline $\begin{array}{l}\text { S. motacillae } \\
\text { Bochkov et Mironov, } 1998\end{array}$ & $\begin{array}{r}\text { Motacilla flava* } \\
\text { (Motacillidae) }\end{array}$ \\
\hline $\begin{array}{l}\text { S. presentalis } \\
\quad \text { Chirov et Kravtsova, } 1995\end{array}$ & $\begin{array}{l}\text { Sturnus vulgaris* } \\
\quad \text { (Sturnidae) } \\
\text { Garrulus glandarius } \\
\quad \text { (Corvidae) } \\
\text { Turdus pilaris } \\
\text { (Turdidae) } \\
\end{array}$ \\
\hline $\begin{array}{l}\text { S. seiurus } \\
\quad \text { (Clark, 1964) }\end{array}$ & $\begin{array}{l}\text { Seiurus aurocapillus* } \\
\quad \text { (Parulidae) } \\
\text { Melospiza melodia } \\
\text { Helmintheros vermivorus } \\
\quad \text { (both Fringillidae) }\end{array}$ \\
\hline $\begin{array}{l}\text { S. weiszii } \\
\text { Skoracki, Hromada } \\
\text { et Tryjanowski, } 2001\end{array}$ & $\begin{array}{l}\text { Lanius excubitor* } \\
\text { (Laniidae) }\end{array}$ \\
\hline $\begin{array}{l}\text { S. cypsiuri } \\
\text { Fain, Bochkov et Mironov, } 2000\end{array}$ & $\begin{array}{l}\text { Cypsiurus parvus } \\
\text { (Apodidae) }\end{array}$ \\
\hline $\begin{array}{l}\text { S. graculae } \\
\text { Fain, Bochkov et Mironov, } 2000\end{array}$ & $\begin{array}{l}\text { Gracula religiosa } \\
\text { intermedia* } \\
\text { (Sturnidae) }\end{array}$ \\
\hline $\begin{array}{l}\text { S. dendrocittae } \\
\text { Fain, Bochkov et Mironov, } 2000\end{array}$ & $\begin{array}{l}\text { Dendrocitta rufa rufa* } \\
\text { (Corvidae) }\end{array}$ \\
\hline $\begin{array}{l}\text { S. carpodaci } \\
\text { Bochkov et Apanaskevich, } 2001\end{array}$ & $\begin{array}{l}\text { Carpodacus erythrinus* } \\
\text { (Fringillidae) }\end{array}$ \\
\hline
\end{tabular}

* type host

(35-40); $t c$ " of tarsi III and IV 70 (70); vi-vi 65 (60-75); ve-ve 75 (70-80); sci-sci 90 (80-90); $h$ - $h 125$ (120-125); d1-d1 25 (20-25); sce-sce 70 (65-75); vi-ve 5 (2-5); vesci 35 (35-40); sci-sce 75 (70-75); l1-ll 80 (75-80); d2$d 245$ (35-45); l2-l2 60 (60); l1-d2 55 (45); d2-l2 80 (75).

Male (Figs. 19, 22, 23). Total body length of four paratypes 425-440.

GNATHOSOMA. Gnathosoma not punctated ventrally. Hypostomal apex as in Fig. 22. Peritremes M-shaped, each transversal branch with 4-6 chambers, each longitudinal branch with 9-11 chambers (Fig. 23). Stylophore 150-155 long.

IDIOSOMA. Propodosomal plate weakly sclerotised, without punctation. The bases of setae $v i$, ve, sci and $d l$ on this plate. Setae vi, ve and sci subequal in length. Hysterosomal plate weakly sclerotised without punctation. The bases of setae $d 2$ on this plate. Setae $l 1, d 2$ and 12 subequal in length. Pygidial plate small. Length ratio of setae $d 5: l 51: 10-12.5$. Two pairs of anal setae. Paragenital setae pgl 1.3-1.5 times longer than $p g 2$. Cuticular striations as in Fig. 19.

LEGS. All coxae without punctation. Coxae of legs III and IV weakly sclerotised, margins indistinct. Epimeres I highly divergent, not fused to epimeres II, often adjoining them. Setae $p$ ' and $p$ " of legs III and IV with 6 tines. Setae $t c$ ' of tarsi III and IV 3.3 times shorter than tc" III and IV.

Length of setae and distance between setal bases $(\mathrm{n}=$ 4): vi 30-35; ve 40-50; sci 35-45; $h$ 80-90; sce 120 ; ll 20; $l 2$ 10-15; $l 5$ 190-205; d1 145; d2 10-15; d5 15-20; ic3 70; $3 b$ 25; 3c 55-60; pg1 30-40; pg2 25; sc3 25; sc4 25. $t c$ ' of tarsi III and IV 15; $t c$ " of tarsi III and IV 5055; vi-vi 70-85; ve-ve 80-90; sci-sci 80-90; h-h 110-125; d1-d1 40-50; sce-sce 80-100; vi-ve 2-5; ve-sci 20-35; $s c i-d 1$ 50; sci-sce 30; l1-l1 75-85; d2-d2 50-55; l2-l2 55; l1-d2 30-35; d2-l2 40.

$\mathrm{T}$ y $\mathrm{p}$ e $\mathrm{h}$ o s t : Passer montanus (L.) (Passeriformes: Ploceidae), the tree sparrow.

S i t e : Quills of secondary feathers.

Ty pe 1 o c a 1 ity: Bardejov, Slovakia; 24.02.1957; leg. T. Weisz.

$\mathrm{T}$ y $\mathrm{p}$ e $\mathrm{s}$ p e c i m e $\mathrm{n} \mathrm{s}$ : Holotype female, 30 paratype females, 4 paratype males and 6 paratype nymphs.

De p o sition of materia 1 : Holotype (No. S-16.1.1), 26 female, 2 male and 6 nymphal paratypes (Nos. S-16.1.2 - S-16.1.35) are deposited at UAM; 2 female paratypes (Nos. S-16.1.36, S-16.1.37) are deposited at SMB; 2 female and 2 male paratypes (Nos. S-16.1.38 - S-16.1.41) are deposited at ZIN.

E t y m o l o g y : The name montanus refers to the specific name of the host - Passer montanus.

Differential diagnosis. Syringophiloidus montanus is closest to $S$. minor (Berlese, 1887) from Passer domesticus (Passeriformes: Ploceidae). In both species the females have the gnathosoma punctated ventrally, setae $v i$ and ve serrate and shorter than 90 and the hysterosomal plate with punctation in posterior part. This new species is distinguished from $S$. minor by the following characters. In the females of $S$. montanus the transversal branches of peritremes have 6-7 chambers and the length of setae $v i$, ve and $s c i$ is 30-40, 50-60 and $90-135$, respectively. In the males the transversal branches have 4-6 chambers and the length of setae $t c$ ' and $t c$ " of tarsi III and IV is 15 and 50-55, respectively; the length of paragenital setae $p g 1$ and $p g 2$ is 30-40 and 25 , respectively. In the females of $S$. minor, the transversal branches have 8-10 chambers and the length 
of setae vi, ve and $s c i$ is $25-30,30-40$ and 50-70, respectively. In the males the lateral branch has 8-9 chambers and the length of setae $t c$ ' and $t c$ " of tarsi III and IV is $20-25$ and $35-45$, respectively; the length of paragenital setae $p g 1$ and $p g 2$ is $70-85$ and 50-60, respectively.

\section{Key to species of Syringophiloidus (females)}

(after Fain et al. 2000; with modifications)

1 One pair of anal setae present S. schoeniclus

- Two pairs of anal setae present ... 2

2 Setae $v e$ at least 90 long ......................................... 3

- Setae ve shorter than 90 ............................................ 6

3 Setae ve longer than 130 .......................... S. cypsiuri

- Setae ve shorter than 130 .... ... 4

4 Propodosomal setae smooth, total body length over 800 S. delichonum

- Propodosomal setae serrate, total body length under 700

5 Longitudinal branches of peritremes with 7-9 chambers (in males, 7-9), length of setae vi and $l 550$ and $375-405$, respectively (length of paragenital setae $p g 1$ in males more than 150) ............................. S. weiszii

- Longitudinal branches of peritremes with 11-14 chambers (in males, 13-14); length of setae vi and $l 5$ 35 and 310-320, respectively (length of paragenital setae $p g 1$ in males 90-110) ...................... S. glandarii

6 Setae $s c i$ shorter than 80 7

- Setae $s c i$ longer than 80 ...8

7 Setae vi, ve and sci thin, setae sci 30-35 long S. dendrocittae

- Setae vi, ve and sci thick, setae sci 45-65 long S. minor
8 Transverse branches of peritremes with more than 4 chambers ................................................................ 9

- Transverse branches of peritremes with less than 4 chambers 12

9 Setae $h$ shorter than 180 ....................... S. montanus

- Setae $h$ longer than 180 ........................................ 10

10 Dorsal plates and coxae not numerously punctuated or without punctation ......................... S. bombycillae

- Dorsal plates and coxae strongly punctuated ........ 11

11 Setae vi, ve and $l 1$ 20-25, 35-40 and 120-140 long, respectively, setae $p g 2$ shorter than 100 .... S. seiurus

- Setae vi, ve and $l 1$ 35-40, 50-65 and 160-190 long, respectively, setae $p g 2$ longer than 100

12 Propodosomal plate strongly punctuated S. carpodaci



- Propodosomal plate not numerously punctuated or without punctation 13

13 Setae sci 190-245 long (setae sci and $l 1$ in males 110-125 and 80-90 long, respectively) .... S. graculae

- Setae sci 80-100 long (setae $s c i$ and $l 1$ in males 3555 and 25-35 long, respectively) ......... S. presentalis

Acknowledgements. I gratefully thank Dr. Tomas Jászay from Šarišské Múzeum Bardejov, Slovakia for help in enabling of present study and material. I am also grateful to Dr. Andre V. Bochkov (Zoological Institute, St. Petersburg, Russia) for his critical reading of the manuscript. Many thanks to Ewelina and Winfried Just (Ohio University, USA) for correcting the English. The present research was partially supported by a UAM grant (206/2000).

\section{REFERENCES}

BOCHKOV A.V. 2001: On systematics of mites of the genus Syringophiloidus (Acari: Syringophilidae) from European part of Russia. Parazitologiya 35: 149-154. (In Russian.)

BOCHKOV A.V., APANASKEVICH D. 2001: Two new species of the family Syringophilidae (Acari: Cheyletoidea) from passeriform birds collected in the Altai. Folia Parasitol. 48: 321-325.

BOCHKOV A.V., MIRONOV S.V. 1998: Quill mites of the family Syringophilidae Lavoipierre, 1953 (Acariformes: Prostigmata) parasitic on birds (Aves) of the fauna of the former USSR. Acarina 6: 3-16.

CASTO S.D. 1974: Quill wall thickness and feeding of Syringophiloidus minor (Berlese) (Acarina: Syringophilidae). Ann. Entomol. Soc. Am. 67: 824.

CHIROV P.A., KRAVTSOVA N.T. 1995: A new genus and new species of mites of the family Syringophilidae. Parazitologiya 29: 370-379. (In Russian.)

CLARK G.M. 1964: The acarine genus Syringophilus in North American birds. Acarologia 6: 76-92.

FAIN A. 1979: Idiosomal and leg chaetotaxy in the Cheyletidae. Int. J. Acarol. 5: 305-310.
FAIN A., BOCHKOV A.V., MIRONOV S.V. 2000: New genera and species of quill mites of the family Syringophilidae (Acari: Prostigmata). Bull. Inst. R. Sci. Nat. Belg. Entomol. 70: 33-70.

FRITSCH W. 1958: Die Milbengattung Syringophilus Heller 1880. Zool. Jahrb. 86: 227-244.

GRANDJEAN F. 1944: Observations sur les acarines de la famille des Stigmaeidae. Arch. Sci. Phys. Nat. 26: 103-131.

KETHLEY J.B. 1970: A revision of the family Syringophilidae (Prostigmata: Acarina). Contrib. Am. Entomol. Inst. 5: 1-76.

MORONY J.J., BOCK W.J., FARRAND J. 1975: Reference List of the Birds of the World. Department of Ornithology, American Museum of Natural History, New York, $x+207$ pp.

SKORACKI M., HROMADA M., TRYJANOWSKI P. 2001: Description of a new species of quill mite Syringophiloidus weiszii sp. n. (Acari, Prostigmata, Syringophilidae) from the Great Grey Shrike Lanius excubitor. Acta Parasitol. 46: 30-34. 
